\title{
Landslide Susceptibility Mapping and Their Rainfall Thresholds Model in Tinalah Watershed, Kulon Progo District, Yogyakarta Special Region, Indonesia
}

\author{
Thema Arrisaldi ${ }^{1}$, Wahyu Wilopo ${ }^{* 1,2}$, and Teuku Faisal Fathani ${ }^{2,3}$ \\ ${ }^{1}$ Department of Geological Engineering, Faculty of Engineering, Universitas Gadjah Mada, Yogyakarta, Indonesia \\ ${ }^{2}$ GAMA-InaTEK, Centre of Excellence of Technological Innovation for Disaster Mitigation, Universitas Gadjah Mada \\ Yogyakarta, Indonesia \\ ${ }^{3}$ Civil and Environment Engineering Department, Faculty of Engineering, Universitas Gadjah Mada Yogyakarta
}

\begin{abstract}
Every year, landslide often occurs in the Tinalah watershed, Kulon Progo Regency. The frequency of landslide events increases after high rainfall intensity. Some factors control landslides, such as slope gradient, land use, geological structure, slope hydrology, and geological condition. This research aims to develop the susceptibility map of the Tinalah watershed and identify the rainfall threshold to trigger a landslide. The development of the susceptibility map using the frequency ratio method with four parameters, including slope, type of rock, land use, and lineament density. The landslide data were collected during the field survey and from the local disaster management authority (BPBD) Kulon Progo. Rainfall data were collected from Japan Aerospace Exploration Agency (JAXA). Soil analysis also was conducted to develop a numerical model to verify the rainfall threshold value. The result shows a high susceptibility of the landslide area is dominated in Tinalah watershed. The rainfall threshold for the low susceptibility of the landslide zone is $I=490.14 D^{-1.404}$ with 5-7 days antecedent rain. The rainfall threshold for the medium susceptibility map is $I=164.32 D^{-0.689} 3-7$ days antecedent rain. Moreover, the rainfall threshold for the high susceptibility of the landslide zone is $111.62 D^{-0.779}$, with 2-7 days of antecedent rain.
\end{abstract}

Keywords: Landslide susceptibility map · Rainfall threshold · Tinalah watershed.

\section{INTRODUCTION}

Landslide is one of the geological disasters that can be controlled by several factors, such as geological condition, geomorphological condition, geological structure, slope hydrology, and land use. A landslide can be triggered by high rainfall intensity, vibration (earthquake), and human activity (Karnawati, 2005). One area with a high risk of landslide in the Kulon Progo Regency is the Tinalah watershed (PVMBG, 2014). Tinalah watershed is located in the north of the Menoreh Mountains. Tinalah water-

\footnotetext{
${ }^{*}$ Corresponding author: W. WILOPO, Department of Geological Engineering, Universitas Gadjah Mada. Jl. Grafika 2 Yogyakarta, Indonesia. E-mail: wwilopo@ugm.ac.id
}

shed has a dendritic pattern controlled by the geological structure with direction northeastsouthwest (Widagdo et al., 2017). There were 47 landslides events from January 2017 until March 2020 (BPBD Kulon Progo, 2020). Generally, landslides in the wet season are due to rainfall. High rainfall intensity can increase the groundwater table, making the slope unstable (Karnawati, 2005). The rainfall intensity that can trigger landslide depends on the geological condition and slope gradient (Brunetti et al., 2013; Ferardi et al., 2018).

Rainfall can trigger a landslide called antecedent rain (Aleotti et al., 2004; Peruccaci et al., 2017). Several researchers showed that shallow landslides could be triggered by high- 
intensity rainfall with a specific duration (Aleotti et al., 2004; Ferardi, 2018; Arrisaldi, 2020 ). This threshold can be used as a standard to develop a landslide early warning system threshold value in the area (Bui et al., 2019).

Tinalah watershed is highly susceptible to a landslide (Wacano and Hadmoko, 2012). Human activity also influences the landslide potential, such as a land-use change to agricultural and settlements (Kumalawati and Junun, 2005). So the susceptibility map needs to be updated regularly based on current field conditions. Therefore, this research aims to develop an update of the susceptibility map and develop a rainfall threshold value for each susceptibility zone.

\section{Methodology}

The research area is located in Tinalah Watershed, Kulon Progo Regency, Yogyakarta Special Region Province, as shown in Figure 1 according to Google Earth images (2020) and the digital elevation model (DEMNAS SRTM, 2021). A survey was conducted to collect data from 104 stop sites, and three soil samples were collected from weathering of andesitic breccia to analyze physical and mechanical properties. The total landslide data is 81 , collected during a field survey and secondary data from BPBD Kulon Progo Regency. Only half of the landslide data was used to develop of susceptibility map. The development of the susceptibility map used the frequency ratio method (Lee and Pradhan, 2007). Remain landslide data will be used to validate the susceptibility map model from the frequency ratio method (Avinash et al., 2008). The frequency ratio used four parameters are slope gradient, lithology, land use, and lineament density. Frequency Ratio $(F R)$ is a method that uses a comparison of the number/area of landslide events to the area of the class by using the equation Equation 1 (Lee and Pradhan, 2007).

$$
F R=\frac{D_{i} / A_{i}}{\sum_{i=1}^{N} D_{i} / \sum_{i=1}^{N} A_{i}}
$$

where, $F R=$ frequency ratio value; $D_{i}=$ number of points/area of a landslide in one class in one factor; $A_{i}=$ the area of a class in one factor; $\sum D_{i}=$ number of points/area of a landslide in all classes in one factor; and $\sum A_{i}=$ total area for one factor.

The results of the frequency ratio method are calculated using the landslide susceptibility index (LSI) method to produce the class. The LSI value is obtained by summing all $F R$ parameter values using Equation 2 (Lee and Pradhan, 2007). The LSI value represents the degree of susceptibility relative to recorded land movement events. The higher of LSI value, the higher the level of susceptibility (Oh et al., 2017).

$$
L S I=F R_{1}+F R_{2}+\cdots+F R_{n}
$$

Rainfall data is obtained from the GSMap. GSMap is Japan's weather satellite that can provide hourly data rainfall intensity (Jaxa, 2020). The rainfall threshold gets from the empirical and physical models (Guzzetti, 2007). An empirical method based on landslides event data and antecedent rainfall data. Data analysis using Statistical Package for the Social Sciences (SPSS) to get exponential regression calculation will show the rainfall threshold and duration of rainfall based on antecedent rainfall data. A physical method based on one point landslide data to get critical safety factor of the slope before landslide happen. This modeling uses Seep/W and Slope/W. Seep/W to get the information of rainfall infiltration to the ground during antecedent rainfall data (Chow et al., 1998; Chen and Young, 2006) and Slope/W to get slope stability condition after the rainfall happen. Notation for the rainfall threshold showed in Equation 3 (Glade, 2000).

$$
I=C+\alpha D_{\beta}
$$

where, $I=$ rainfall intensity; $D=$ duration; $C$, $\alpha$, and $\beta=$ empirical parameters.

\section{Result AND Discussion}

The landslide susceptibility map has four parameters: slope map, geological map, land use map, and lineament density map, as shown in Figure 2. The landslide susceptibility map has four parameters: slope map, geological map, land use map, and lineament density map, as shown in Table 1.

Step after defining the $F R$ number for each parameter, the next step is to make a land- 


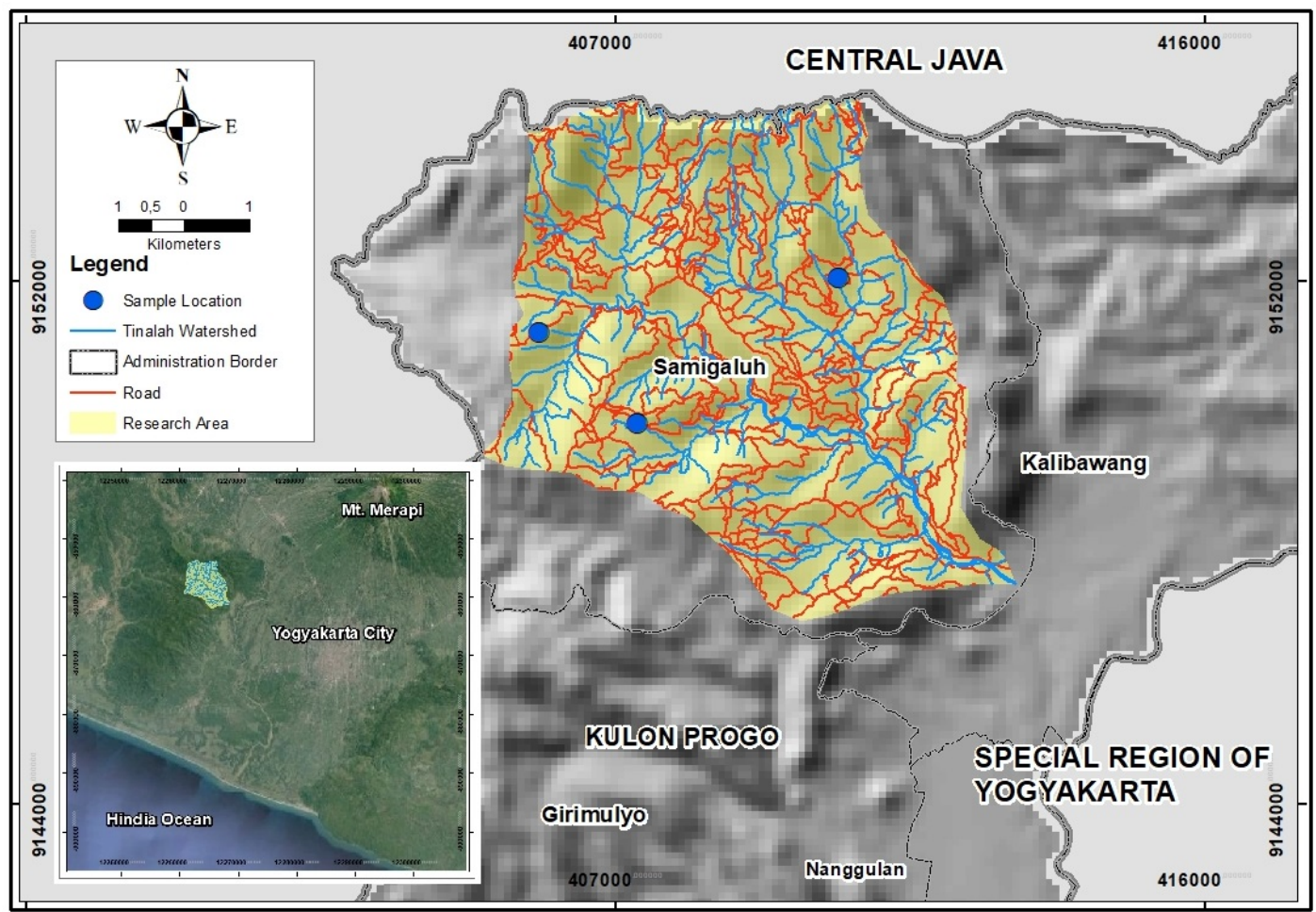

FIGURE 1. Research area based on the Google Earth images (2020) and DEMNAS SRTM (2021).
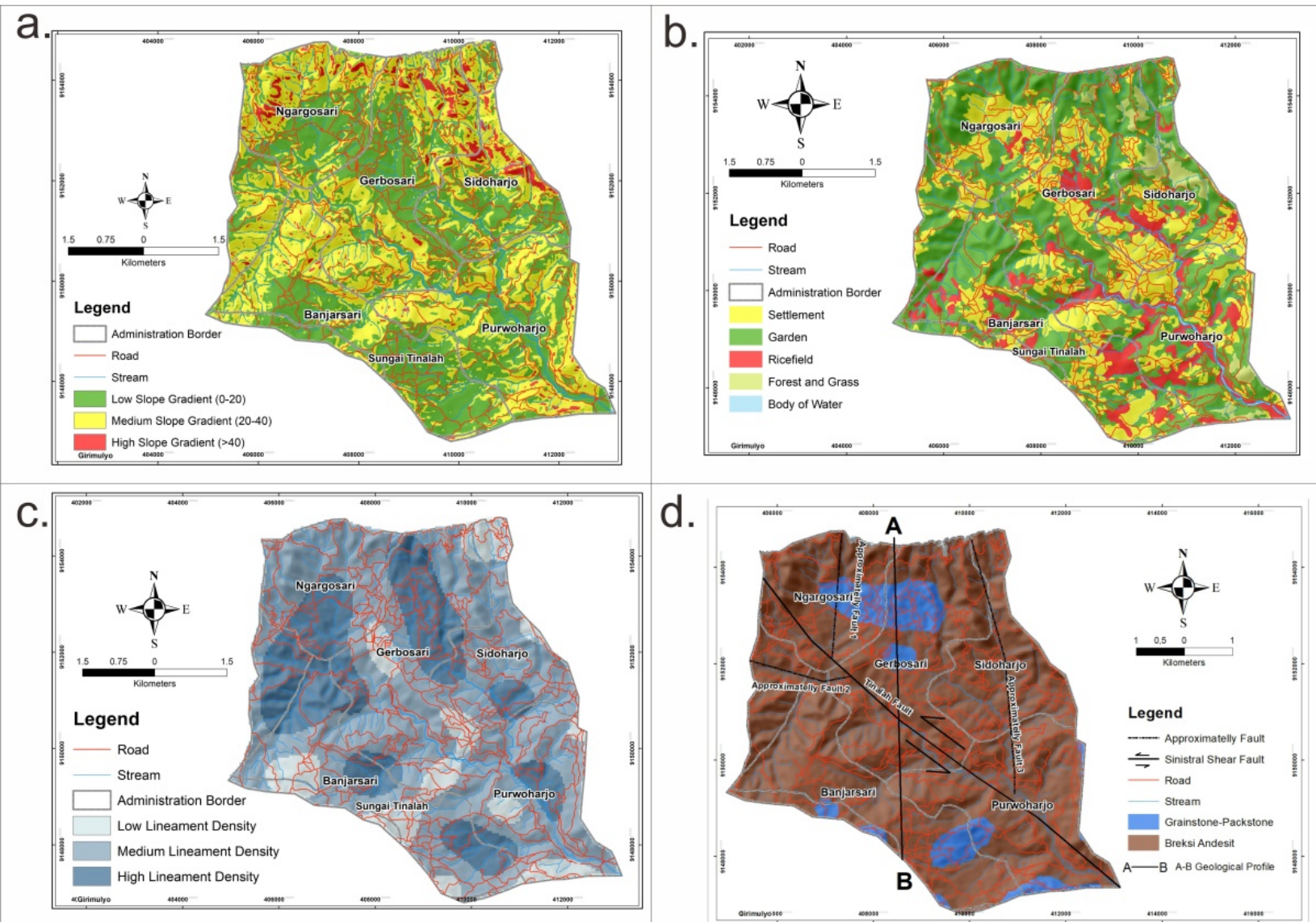

FIGURE 2. Parameters map: (a) slope gradient map; (b) land use map; (c) lineament density map; (d) geological map. All the maps based on the DEMNAS SRTM (2021). 
TABLE 1. Frequency Ratio (FR) calculation.

\begin{tabular}{|c|c|c|}
\hline Paran & Sub-parameters classes & FR \\
\hline $\begin{array}{l}\text { Slope } \\
\text { Gradient }\end{array}$ & $\begin{array}{l}\text { Low slope gradient }(0-20) \\
\text { Moderate slope gradient } \\
(>20-40) \\
\text { High slope gradient }(>40)\end{array}$ & $\begin{array}{l}0.93 \\
1.12\end{array}$ \\
\hline Lithology & $\begin{array}{l}\text { Andesite breccia } \\
\text { Grainstone-packstone }\end{array}$ & $\begin{array}{l}1.04 \\
0.64 \\
\end{array}$ \\
\hline Land $x$ & $\begin{array}{l}\text { Settlement } \\
\text { Rice field and garden } \\
\text { Forest and bush }\end{array}$ & $\begin{array}{l}1.25 \\
0.91 \\
0.4 \\
\end{array}$ \\
\hline $\begin{array}{l}\text { Lineament } \\
\text { Density }\end{array}$ & $\begin{array}{l}\text { Low lineament density } \\
\text { Moderate lineament density } \\
\text { High lineament density }\end{array}$ & $\begin{array}{l}2.39 \\
0.54 \\
1.44\end{array}$ \\
\hline
\end{tabular}

slide susceptibility map and validate the susceptibility map. The map is made by overlaying all parameters by using a geographic information system (GIS). Using the natural breaks Jenks method, the area was divided into low, medium, and high susceptibility zones. The low susceptibility of the landslide has $12 \%$ of the area, the medium susceptibility zone of the landslide has $27 \%$ of the area, and the high susceptibility of the landslide has $61 \%$ of the area, as shown in Figure 3a.

High susceptibility is wider than the previous susceptibility map developed by PVMBG (2014). It is probably due to land-use change in the Tinalah Watershed. Many areas changed from forest to agricultural or settlement. Therefore, many landslides were found in the settlement area, which changed the slope gradient to get a wider flat area.

Validation of the susceptibility map used 40 landslides events that spread evenly. Landslide susceptibility index (LSI) was made by classifying the susceptibility map into ten classes and counting the frequency of landslide events for each class (Figure 3b).

The area under curve (AUC) value was calculated from the accumulation of landslide frequency as a curve, as shown in Figure 4 . The result value of $A U C$ is $80.75 \%$. It means that the accuracy of the susceptibility map is very good (Lee and Pradan, 2007).

\subsection{Rainfall threshold}

The total landslide that has complete information, including rainfall, is 47 . Therefore the development of rainfall threshold only uses 47 data in the Tinalah watershed. Rainfall data were collected from Japan Aerospace Exploration Agency (JAXA, 2020). Three susceptibility zones were identified based on the susceptibility map from the frequency ratio method. The low susceptibility landslide zone has four landslide data. The rainfall threshold value in this zone is $I=82.81 D^{-0.031}$, with $5-7$ days antecedent rain, as shown in Figure 5.

The medium susceptibility of the landslide zone has 13 confirmed landslide data. The rainfall threshold value in this zone is $I=$ $67.82 D^{-0.021}$, and it has 3-7 antecedent rain duration to trigger a landslide, as shown in Figure 6.

The high susceptibility landslide zone has 30 confirmed landslide events. The rainfall threshold value in this zone is $I=54.988 D^{-0.77}$, with 2-7 antecedent rain duration, as shown in Figure 7.

\subsection{Model verification}

The empirical rainfall threshold was validated by numerical modeling from the landslide in Pucung Subvillage, Ngargosari Village, Samigaluh District. This landslide is located in the high landslide susceptibility zone. The landslide occurred due to 2 days of rainfall, with a total intensity of $67.37 \mathrm{~mm}$. Landslide dimension has $15 \mathrm{~m}$ of height, $35 \mathrm{~m}$ for cracks wide, and $48^{\circ}$ gradient.

The lithology of the slope is material from weathering of andesite breccia with cohesion value $30.23 \mathrm{kPa}$, friction angle value $12^{\circ}$, and bulk density $19.78 \mathrm{kN} / \mathrm{m}^{3}$. The soil can be classified as sandy clay soil (ASTM, 2001). The slope materials were assumed as homogenous materials in the model.

Analysis of slope stability using Seep/W was run for four days with a constant rainfall intensity of $30 \mathrm{~mm} /$ day. The initial condition of the slope shows that the slope is in a stable condition with a safety factor value of 1.432, as shown in Figure 8a. However, when the model was running for two days of constant rainfall intensity, it showed a decreasing safety factor that reached 1.068, as shown in Figure 8b. It means that the slope has a critical to move. The total rainfall intensity in two days is $60 \mathrm{~mm}$. The estimation of rainfall-triggered landslide accord- 


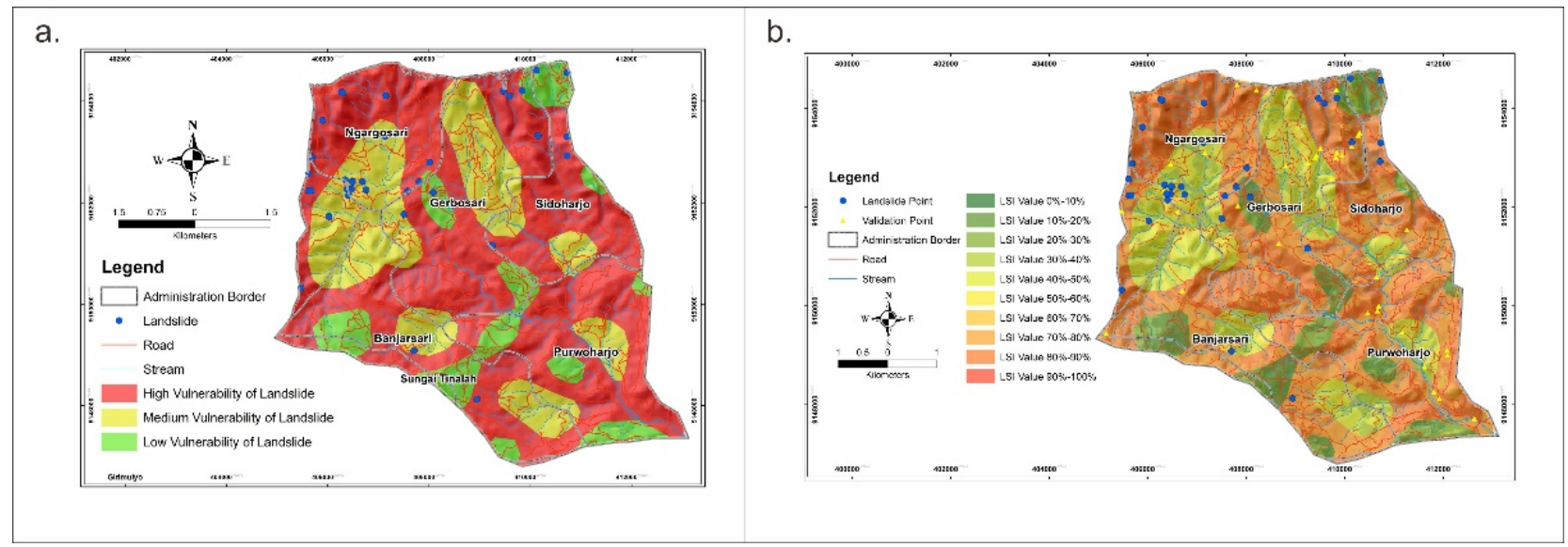

FIGURE 3. (a) susceptibility map based on FR method; (b) LSI map for validation. All the maps based on the DEMNAS SRTM (2021).

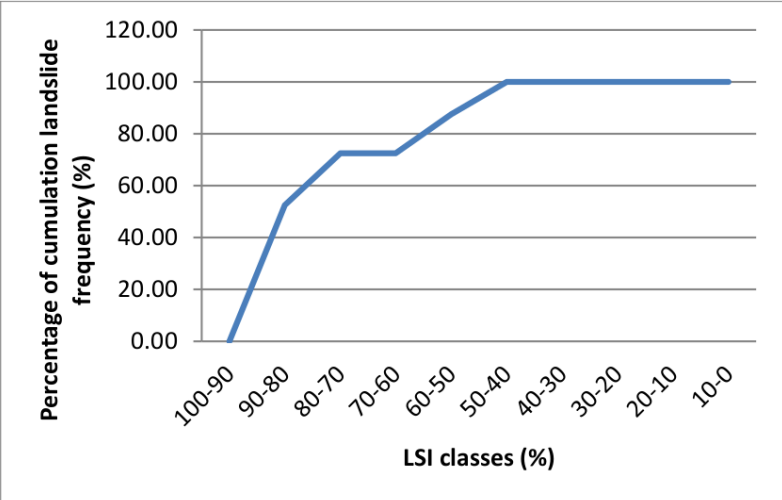

FIGURE 4. Cumulative landslide frequency's curve.

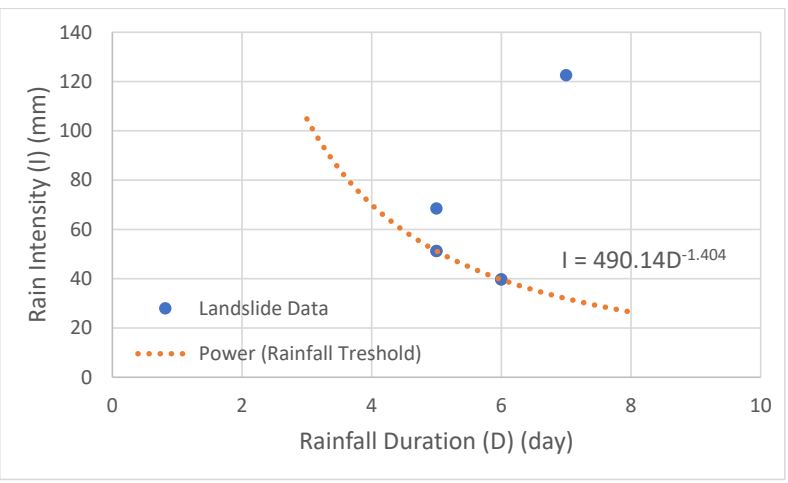

FIGURE 5. Rainfall threshold for the low susceptibility of landslide $I=490.14 D^{-1.404}$.

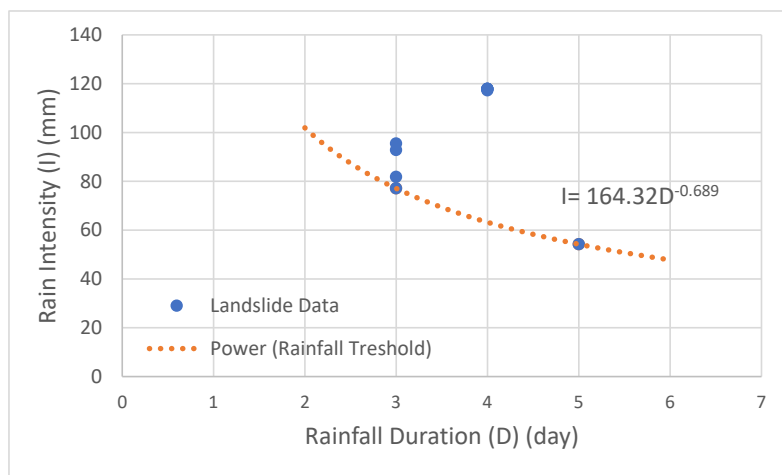

FIGURE 6. Rainfall threshold for medium susceptibility map $I=164.32 D^{-0.689}$.

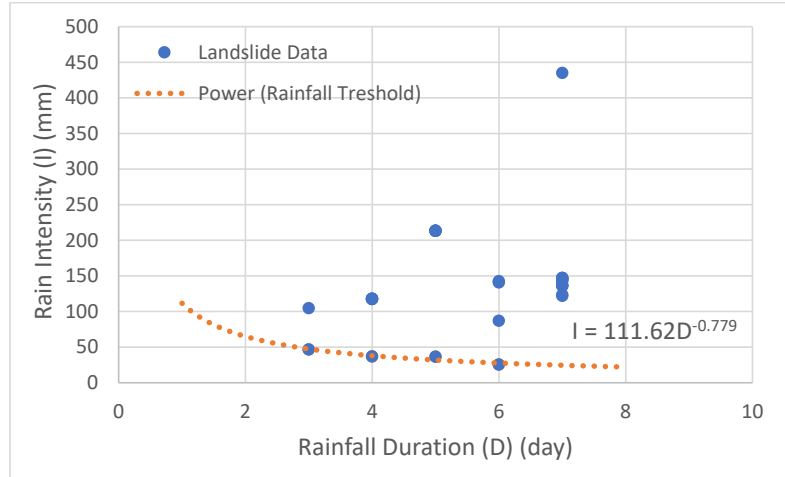

FIGURE 7. Rainfall threshold for the high susceptibility of landslide $I=111.62 D^{-0.779}$. 


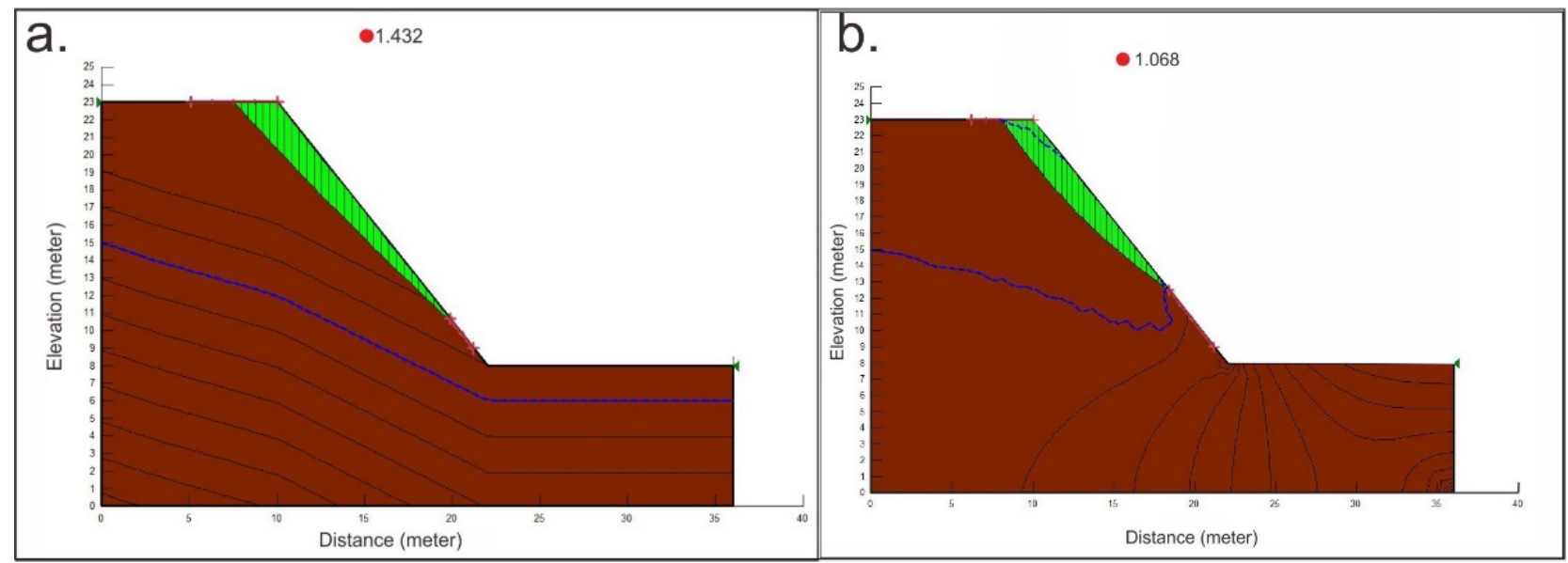

FIGURE 8. (a) Initial slope stability; (b) Critical slope stability after two days of rainfall with a total intensity of $58.40 \mathrm{~mm}$.

ing to the rainfall threshold equation for high susceptibility of the landslide zone is $65.1 \mathrm{~mm}$, and the actual data during the landslide event is $67.37 \mathrm{~mm}$. Therefore, those values are not significantly different. The result from the empirical model was confirmed with a numerical model.

\section{CONCLUSION}

The susceptibility map of the Tinalah watershed can be divided into three zones, namely low, medium, and high susceptibility. The map has very good accuracy based on the criteria of AUC value of $80.75 \%$. Around $61 \%$ of the total area dominates the high susceptibility zone. The high susceptibility area is more significant compared to the previous susceptibility map developed by PVMBG. It is due to land-use change in this area. The numerical model confirmed the empirical model of the rainfall threshold for triggering a landslide. The rainfall threshold for the low, medium, high susceptibility of the landslide zone areas are $I=490.14 D^{-1.404}, I=164.32 D^{-0,689}$, and $I=$ $111.62 D^{-0.779}$, respectively.

\section{ACKNOWLEDGEMENTS}

We thank the PUI Gama-InaTek Faculty of Engineering, Universitas Gadjah Mada that gave financial support. We also thank Balai Sabo, Ministry of Public Works and Regional Disaster Management Agency (BPBD) of Kulon Progo Regency, for providing landslide information.

\section{REFERENCES}

Aleotti, P. (2004) A Warning System for RainfallInduced Shallow Failures. Engineering Geology, 73: 247-265.

American Standard Testing and Material (ASTM). (2001) C128-1: Standard Test Method for Density, Relative Density (Specific Gravity), and Absorption of Fine Aggregate, 100 Barr Harbor Drive: United States.

Arisaldi, T. (2020) Evaluation of Geological Conditions and Rainfall Threshold Causes of Landslides in the Tinalah River Basin, Kulon Progo, Yogyakarta, Department of Geological Engineering, Gadjah Mada University, Thesis-Unpublish (in Indonesia).

Avinash, K.G., Diwakar, P.G., Joshi, N.V., and Ramach, T.V. (2008) Landslide susceptibility mapping in the downstream region of Sharavathi river basin, Central Western Ghats. In Proceedings of the 24th annual symposium on space and technology ISROIISc technology cell, Indian Institute of Science.

Brunetti, M. T., Luino, F., Vennari, C., Peruccacci, S., Biddoccu, M., Valigi, D., \& Ardizzone, F. (2013) Rainfall thresholds for possible occurrence of shallow landslides and debris flows in Italy. In Dating Torrential Processes on Fans and Cones, Springer, Dordrecht. pp. 327-339.

Bui T.A., Fathani T.F., Wilopo W. (2019) Landslide Risk Assessment for Designing Monitoring and Early Warning System, Journal of Applied Geology 4(1):1-8.

Chen, L. and Young, M.H. (2006) Green Ampt Infiltration Model for Sloping Surface, Water Resources Research 42(W0742): 9p.

Chow, V.T., Maidment D.R., Mays, L.W., 1988, Applied Hydrology, Singapura; McGraw-Hill International Editions Civil Engineering Series, 572p.

DEMNAS SRTM (2020) Digital Elevation Model (DEM) of Kulon Progo Regency, Yogyakarta Spe- 
cial Province. https://tanahair.indonesia.go.id/ demnas/\#/, accessed on January 10, 2020.

Ferardi, F. D., Wilopo, W., Fathani, T. F. (2018) Rainfall Thresholds for Landslide Prediction in Loano Subdistrict, Purworejo District Central Java Province. Journal of Applied Geology 3(1): 23-31.

Glade, T. (2000) Modelling landslide triggering rainfall thresholds at a range of complexities.- Landslides in Research, Theory, and Practice, Proceedings of the 8th International Symposium on Landslides, 26-30 June 2000, Cardiff, UK, Thomas Telford, 2, 633-640.

Google Earth (2020) Google earth images of Kulon Progo Regency, Yogyakarta Special Province. Accessed on January 15, 2020.

Guzzetti, F., Peruccacci, S., Rossi, M., Stark, C. (2007) Rainfall thresholds for the initiation of landslides in central and southern Europe. Meteorol Atmos Phys 98:239-267.

Japan Aerospace Exploration Agency (JAXA) (2020) JAXA Global Rainfall Watch (GSMaP_NRT), http://sharaku.eorc.jaxa.jp/GSMaP/index_e.htm, Accessed on July 25, 2020.
Karnawati, D. (2005) Landslide Natural Disasters in Indonesia and its Countermeasures. Department of Geological Engineering, Faculty of Engineering, Gadjah Mada University, Yogyakarta. 232 p. (in Indonesia).

Kulon Progo Local Disaster Management Authority (BPBD Kulon Progo). (2020) Disaster Events Data in Kulon Progo Regency, BPBD Kulon Progo, Kulon Progo.

Kumalawati, R. and Sartohadi, J. (2005) Valuable economic of landslide disaster and erosion to agricultural land in Tinalah Watershed. Master Geography Program, Faculty of Geography, Thesis, Unpublish. (in Indonesia).

Lee, S. and Pradhan, B. (2007) Landslide hazard mapping at Selangor, Malaysia using frequency ratio and logistic regression models. Landslides 4:33-41.

Oh H.J, Lee, S., Hong, S.M. (2017) Landslide Susceptibility Assessment Using Frequency Ratio Technique with Iterative Random Sampling, Journal of Sensors Volume 2017, Article ID 3730913, 21 p. 